\title{
Temperature climatology and trend estimates in the UTLS region as observed over a southern subtropical site, Durban, South Africa
}

\author{
H. Bencherif ${ }^{1}$, R. D. Diab ${ }^{2}$, T. Portafaix ${ }^{1}$, B. Morel ${ }^{1}$, P. Keckhut ${ }^{3}$, and A. Moorgawa ${ }^{2}$ \\ ${ }^{1}$ Laboratoire de l'Atmosphère et des Cyclones, UMR 8105 CNRS/Université/Météo-France, Université de La Réunion, B.P \\ 7151, 97715, Saint-Denis, Reunion Island, France \\ ${ }^{2}$ University of KwaZulu-Natal, Durban 4041, South Africa \\ ${ }^{3}$ Service d'Aéronomie, UMR-CNRS 7620, B.P. 3, Verrières-le-Buisson, France
}

Received: 20 September 2005 - Published in Atmos. Chem. Phys. Discuss.: 20 February 2006

Revised: 30 October 2006 - Accepted: 6 November 2006 - Published: 7 November 2006

\begin{abstract}
Temperature trends in the UTLS region are under-reported, particularly in the Southern Hemisphere, and yet temperature is one of the most important indicators of changes in dynamical and radiative processes in the atmosphere. Here radiosonde data from Durban, South Africa $\left(30.0^{\circ} \mathrm{S}, 30.9^{\circ} \mathrm{E}\right)$ over the period 1980 to 2001 (22 years) between 250 and $20 \mathrm{hPa}$ are used to derive a mean temperature climatology and to determine trends. The seasonal cycle at the $250-\mathrm{hPa}$ level is anti-correlated with the seasonal cycles at the 150-hPa and 100-hPa heights. The 100-hPa level (local tropopause) exhibits a minimum temperature in late summer and a maximum in winter, and closely corresponds to previous results for tropical regions. Based on a Fourier analysis, both the annual cycle (AO) and the semi-annual cycle (SAO) are dominant, although the former is about 4 times stronger. The AO is strongest at the $100-\mathrm{hPa}$ height. A trend analysis reveals a cooling trend at almost all heights in the UTLS region, with a maximum cooling rate of $1.09 \pm 0.41 \mathrm{~K}$ per decade, at $70-\mathrm{hPa}$. Cooling rates are in good agreement with other studies and are slightly higher in summer than in winter.
\end{abstract}

\section{Introduction}

Temperature controls the rates of chemical reactions and thus ozone abundance (and vice versa), and is one of the most important parameters in terms of its influence on dynamical and radiative processes in the terrestrial atmosphere, particularly in the upper troposphere - lower stratosphere (UTLS) region. The UTLS is a region where significant changes are taking place that have the potential to perturb the Earth's climate in the coming decades.

Correspondence to: $\mathrm{H}$. Bencherif

(hassan.bencherif@univ-reunion.fr)
Since dynamical activity is closely linked to temperature, temperature trends are a useful indicator of changes in dynamical processes and can contribute to a better understanding thereof. Indeed, any change in activity of gravity waves, equatorial Kelvin waves and Rossby planetary waves may have a consequent effect on mass and energy fluxes, including stratosphere-troposphere exchanges as well as tropicalmidlatitude exchanges.

Relatively few studies of trends in temperature in the UTLS region have been undertaken. One of the most complete studies is that of Oort and Liu (1993). Their study is based on the global rawinsonde network of more than 700 stations, of which $70 \%$ are in the $\mathrm{NH}$ and about $50 \%$ in the $30-60^{\circ} \mathrm{N}$ latitude band. Only slightly more than $15 \%$ of the stations are situated in the Southern Hemisphere (SH).

Most of the temperature trend studies that have been performed for the $25-70 \mathrm{~km}$ altitude range, have used Indian, American, Japanese and Russian rocket-sondes (Mohanakumar, 1994; Keckhut et al., 1999a, b; Kokin and Lysenko, 1994), and French lidar measurements (Hauchecorne et al., 1991; Keckhut et al., 1995). Some authors have performed trend analyses from the large ozonesonde databases (Logan, 1994; Harris et al., 1997; Bodeker et al., 1998), but again, these are predominantly available for the $\mathrm{NH}$.

Within this context, this study focuses on a climatological and trend analysis of temperature, in a subtropical region where data are sparse. Regular upper-air radiosonde data recorded by the South African Weather Service (SAWS) over Durban $\left(30.0^{\circ} \mathrm{S}, 30.9^{\circ} \mathrm{E}\right)$, situated on the east coast of South Africa, are used as the basis of the temperature climatology and trend analysis.

Theoretical studies, transport models and in situ observations have shown that at subtropical latitudes, vertical and horizontal exchange processes are expected and have been observed (Grant et al., 1994; Holon et al., 1995; Vaughan and Timmis, 1998; O'Connor et al., 1999). Furthermore, recent observational studies have shown that in the southern

Published by Copernicus GmbH on behalf of the European Geosciences Union. 


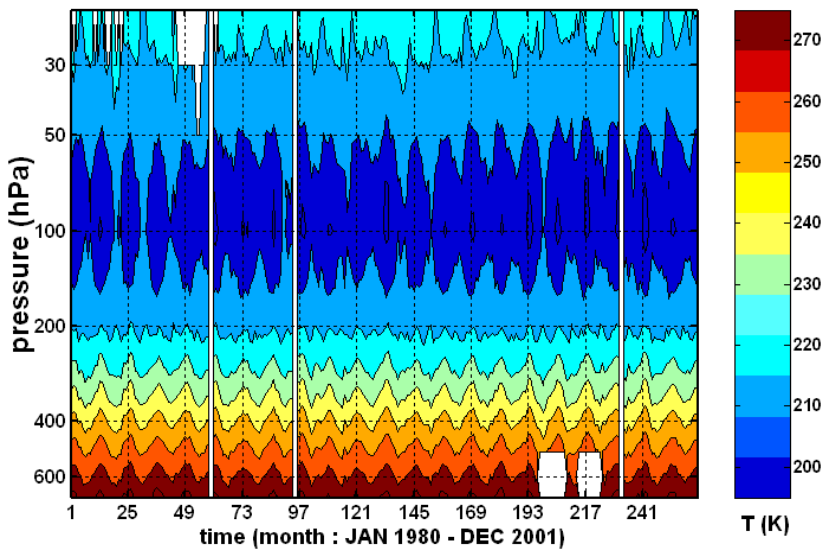

Fig. 1. Time-height section of temperature over Durban, South Africa, obtained with data from January 1980 to December 2001.

subtropics, within the UTLS region, many dynamical processes, such as subtropical tropopause breaks (Baray et al., 1998), planetary-scale tropopause fold events (Baray et al., 2000) and isentropic horizontal exchanges in the low stratosphere through the southern subtropical barrier (Bencherif et al., 2003; Portafaix et al., 2003) take place. These processes play an important role in the transfer of energy, mass and tracers between the tropics and the mid-latitudes.

Temperature trend analyses in tropical regions based on rocket data (Keckhut et al., 1999) have revealed a significant long-term cooling ( 1 to $3 \mathrm{~K}$ per decade), greater by a factor of 2, than model predictions. In general, Stratospheric Temperature Trend Assessments performed as part of the SPARC/WCRP project (Ramaswamy et al., 1999) and the WMO (1999) assessment have noted that numerical models predict a smaller cooling in the stratosphere than that detected in observed data series.

The outline of this paper is as follows. Details on the data and data analysis are presented in the next section. Section 3 presents the variability and trends of temperature and its climatology over Durban. In the last section our results are discussed and compared with previous observational analyses.

\section{Data set}

The data used in this study are daily radiosonde temperature measurements recorded at the Durban international airport $\left(30.0^{\circ} \mathrm{S}, 30.9^{\circ} \mathrm{E}\right)$ by the SAWS for the 22-year period from January 1980 to December 2001. The study focuses on temperature time series recorded at 8 pressure levels, i.e., $250,200,150,100,70,50,30$ and $20 \mathrm{hPa}$, corresponding approximately to the heights of $10,12,14,16,18,20,23$ and $26 \mathrm{~km}$, respectively. Hereafter we will refer to levels 250,200 and $150 \mathrm{hPa}$ as tropospheric, and levels with pressure less than $100 \mathrm{hPa}$ as stratospheric. According to Randel et al. (2000), based on ECMWF, UKMO and NCEP data, the 100-hPa height tracks nearly identically the tropopause height. Hence the $100-\mathrm{hPa}$ level will be referred to as the tropopause level.

The SAWS undertakes regular radiosonde launches twice a day, at approximately the same time (within $\pm 15 \mathrm{~min}$ ), in the early morning and afternoon, i.e., $\cong 01: 00$ and $\cong 12: 35 \mathrm{LT}$, respectively. In order to limit tidal biases, morning and afternoon data are used separately. Moreover, data quality checks were performed and all unrealistic readings were removed. As expected, the percentage of reliable afternoon data decreases with increasing height, and is $96.6 \%$, $96.3 \%, 95.9 \%, 94.7 \%, 91.3 \%, 86.1 \%, 73.1 \%, 54.8 \%$, at 250 , $200,150,100,70,50,30$ and $20 \mathrm{hPa}$ levels, respectively. No adjustments or interpolations were made.

Many authors have emphasised that changes in instruments may lead to apparent discontinuities in temperature records with magnitudes that can be as large as the observed upper-air trends, notably in the tropics and SH (Angell, 1988; Gaffen, 1994). The introduction of new types of radiosondes is one of the potential sources of data heterogeneity, and should be taken into account. For the studied location of Durban, no instrumental change was reported during the 1980 2001 period according to the SAWS archives. The Väisälä RS80-15 model was used throughout the period.

\section{Results}

\subsection{Climatological temperatures}

For both climatology and trend assessments data have been reduced to monthly averages at each of the pressure levels (see Fig. 1). Mean monthly climatological temperature values, as depicted in Figs. 2a and b, were calculated from more than 520 daily values. All the mean monthly climatological temperatures and corresponding standard deviations are given in Table 1.

Figure 2 shows that the seasonal variations of temperature at the $150-\mathrm{hPa}$ and local tropopause $(100-\mathrm{hPa})$ heights are quite similar, but are anti-correlated $(-0.93$ and -0.97 , respectively) with the $250-\mathrm{hPa}$ temperature variations. The minimum temperature at the tropopause is about $199 \mathrm{~K}$, and appears during austral summer in February; while the maximum temperature (about $208 \mathrm{~K}$ ) at the tropopause is obtained during austral winter (June-August). Even though Durban is a subtropical site, the observed annual cycle at the tropopause level is very similar to results obtained by Randel et al. (2000) for tropical regions. Based on radiosonde and NCEP data they found that the tropical tropopause exhibited a minimum temperature during austral summer and a maximum during austral winter.

As suggested visually by the temperature time-height cross-section shown in Fig. 1, Fourier analysis, performed at different heights, highlights two dominant seasonal oscillations: an annual oscillation (AO) and a semi-annual 
Table 1. Mean monthly temperature (K) and corresponding standard deviations derived from Durban-SAWS data covering the period from January 1980 to December 2001.

\begin{tabular}{|c|c|c|c|c|c|c|c|c|c|c|c|c|}
\hline $\begin{array}{l}\text { height } \\
(\mathrm{hPa})\end{array}$ & Jan & Feb & March & April & May & June & July & Aug & Sep & Oct & Nov & Dec \\
\hline \multirow[t]{2}{*}{250} & 234.5 & 235.3 & 233.2 & 230.1 & 228.6 & 228.3 & 228.2 & 228.8 & 228.9 & 229.7 & 231.4 & 232.6 \\
\hline & 2.6 & 2.8 & 2.4 & 2.3 & 2.6 & 2.7 & 2.8 & 3.3 & 2.6 & 2.2 & 2.1 & 2.2 \\
\hline \multirow[t]{2}{*}{200} & 219.4 & 220.5 & 218.8 & 217.3 & 217.1 & 218.2 & 219.0 & 219.1 & 218.1 & 217.6 & 217.3 & 218.0 \\
\hline & 2.6 & 2.7 & 2.6 & 2.9 & 3.4 & 3.8 & 3.9 & 3.7 & 3.7 & 3.2 & 2.8 & 2.4 \\
\hline \multirow[t]{2}{*}{150} & 208.9 & 209.2 & 209.7 & 211.1 & 212.6 & 213.8 & 214.1 & 213.9 & 213.1 & 212.6 & 210.9 & 209.8 \\
\hline & 2.3 & 2.2 & 2.5 & 3.0 & 3.5 & 3.4 & 3.3 & 3.4 & 3.6 & 3.1 & 2.7 & 2.8 \\
\hline \multirow[t]{2}{*}{100} & 200.1 & 199.7 & 201.6 & 204.5 & 206.8 & 207.6 & 207.9 & 207.9 & 207.4 & 206.7 & 204.1 & 202.4 \\
\hline & 2.8 & 2.7 & 3.2 & 3.3 & 3.2 & 3.1 & 3.3 & 3.7 & 3.6 & 3.2 & 2.8 & 2.7 \\
\hline \multirow[t]{2}{*}{70} & 202.1 & 201.9 & 203.8 & 205.8 & 207.6 & 208.3 & 208.6 & 209.2 & 209.7 & 208.3 & 205.9 & 203.4 \\
\hline & 3.1 & 2.7 & 2.9 & 2.8 & 2.9 & 3.4 & 3.4 & 3.2 & 3.0 & 2.8 & 2.6 & 2.9 \\
\hline \multirow[t]{2}{*}{50} & 209.9 & 209.5 & 210.5 & 211.0 & 212.1 & 212.6 & 213.0 & 213.8 & 214.3 & 213.0 & 211.2 & 210.2 \\
\hline & 2.8 & 2.5 & 2.4 & 2.3 & 2.5 & 2.7 & 3.0 & 2.8 & 2.9 & 2.4 & 2.3 & 2.8 \\
\hline \multirow[t]{2}{*}{30} & 218.5 & 218.8 & 219.5 & 219.1 & 219.0 & 219.0 & 219.2 & 219.4 & 219.4 & 218.5 & 217.4 & 218.1 \\
\hline & 2.2 & 2.2 & 2.1 & 2.1 & 2.2 & 2.5 & 3.2 & 2.7 & 2.6 & 2.6 & 2.2 & 2.6 \\
\hline \multirow[t]{2}{*}{20} & 224.4 & 224.8 & 225.3 & 224.3 & 223.5 & 223.2 & 222.9 & 222.7 & 222.6 & 222.1 & 221.5 & 223.1 \\
\hline & 2.3 & 2.2 & 2.0 & 2.1 & 2.5 & 2.8 & 3.2 & 2.9 & 2.6 & 2.8 & 2.3 & 2.7 \\
\hline
\end{tabular}

oscillation (SAO). The corresponding vertical profiles of the $\mathrm{AO}$ and SAO in the subtropical UTLS region under consideration are depicted in Fig. 3. In general, the subtropical UTLS is dominated by the $\mathrm{AO}$, with the $\mathrm{AO}$ amplitudes about 4 times stronger than the SAO amplitudes. It is noted that in the lower stratosphere (70-hPa), the SAO shows weaker amplitudes than in the upper troposphere (200-hPa).

The SAO has its maximum amplitude at 250-hPa where the AO shows its minimum (Fig. 3). The seasonal variation of temperature at $200-\mathrm{hPa}$ appears to be driven by the SAO cycle. Thus, it is evident in Fig. 2a that the coldest temperatures at 200-hPa appear in May and November, during the autumn and spring equinoxes respectively, while the highest temperatures are observed in February and August.

The AO shows a maximum-amplitude at the tropopause height, and is dominant in the lower stratosphere, at the 70and 50-hPa levels (Fig. 3). At the 30- and 20-hPa heights both the SAO and AO show weak amplitudes.

\subsection{Trend estimation}

In the present study, temperature trends from 22 years of upper-air data over Durban, have been investigated using a statistical trend model adapted from the AMOUNT and AMOUNT- $\mathrm{O}_{3}$ models for ozone and temperature trend assessment (Hauchecorne et al., 1991; Mohanakumar, 1994; Keckhut et al., 1995; Guirlet et al., 2000). It is based on a multivariate least-squares method and takes into account seasonal variations, i.e., annual and semi-annual cycles, and uses parametric functions in order to consider the QBO, the ENSO, and the 11-years solar cycles. The solar cycle is de- fined as a linear function and is correlated with the solar flux at $10.7 \mathrm{~cm}$.

In the trend model, temperature $T$ at time $t$ and height $z$ is represented by the equation:

$T(t, z)=\sum_{k=1}^{p} a(z, k) \times c(t, k)+T^{\prime}(t, z)$

where $\mathrm{c}(t, k)$ describes the temporal evolution of the forcing $k ; \quad a(z, k)$ is a coefficient computed by the model for the forcing $k$; and $T^{\prime}(t, z)$ is the residual term. A least squares method computes the coefficients a $(z, k)$ in order to minimise the quantity:

$\chi^{2}(z)=\left[\sum_{t} T(t, z)-\sum_{k} a(z, k) \times c(t, z)\right]^{2}$

Prior to trend error computation the autocorrelation of the residuals must be considered in order to examine data independency. In the present work, temperature measurements are derived from daily systematic sampling and have been reduced to monthly means, per pressure level. With such sampling the autocorrelation of the residuals should be low, following Tiao et al. (1990) finding: the precision of trend estimates depends critically on the magnitude of autocorrelations in the monthly observations, but it is not sensitive to the temporal sampling rates of daily measurements under systematic sampling.

Taking into account the autocorrelation coefficient $\varphi$, the trend uncertainty is thus given, as shown in the Appendix of 
(a)

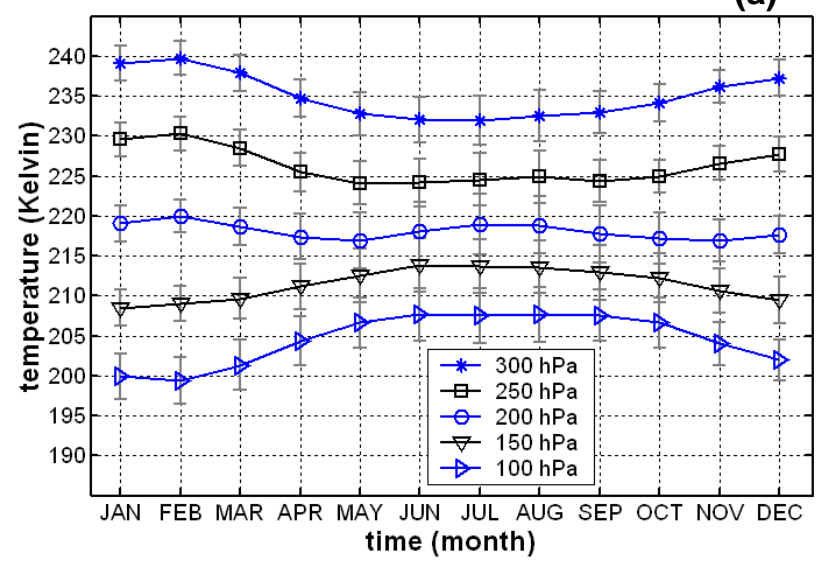

(b)

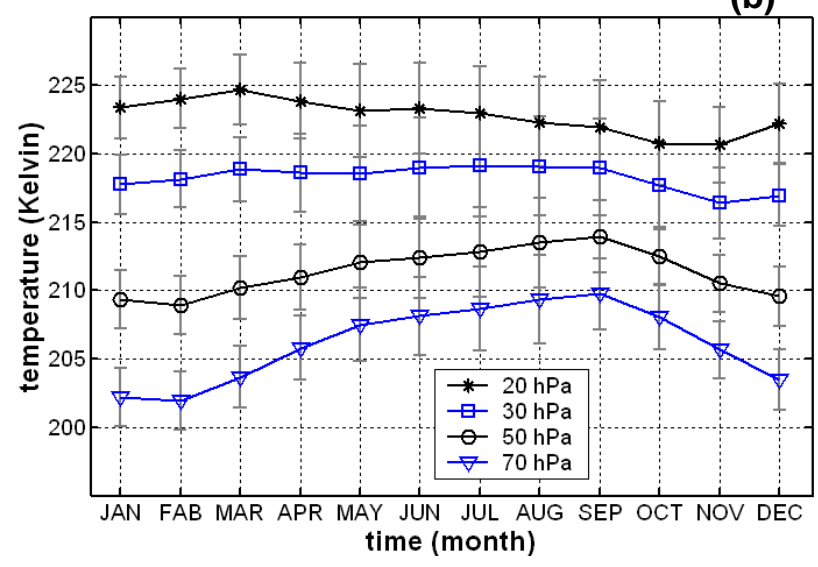

Fig. 2. Time evolution of monthly averaged temperatures per height: (a) in the upper troposphere and (b) in the lower stratosphere over Durban (see legends).

Logan (1994), through the variance formula of the residual term :

$\sigma_{r}^{2}(z)=\frac{\chi^{2}(z)}{n-p} \times \sqrt{\frac{1+\varphi}{1-\varphi}}$

where $n$ and $p$ represent measurement and forcing numbers, respectively.

One of the most significant factors that influence temperature trends, notably in the lower stratosphere, is the large aerosol enhancement following a volcanic eruption (WMO, 1995). Due to solar radiation and terrestrial infrared radiation increases caused by major eruptions, aerosol loading results in a warming in the stratosphere, particularly in the tropical and subtropical regions (Labitzke and McCormick, 1992).

Taking into account the temporal coverage of the dataset used in the present study, trend analyses may be biased if post-Pinatubo data are not removed or adjusted for volcanic influence. Pinatubo erupted in June 1991 and has injected a large quantity of gases and aerosols into the stratosphere up to a height of $30 \mathrm{~km}$, with most of the volcanic clouds in

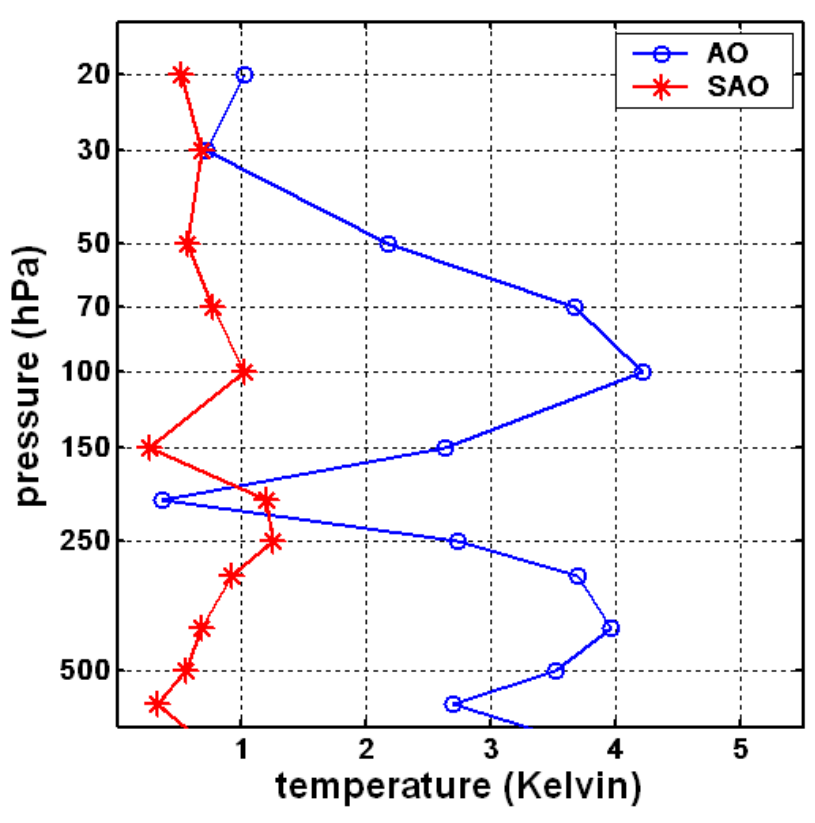

Fig. 3. Vertical profiles of the annual and the semi-annual oscillations as derived from SAWS data recorded over Durban (see legend).

the 20-25 km altitude range (McCormick and Viega, 1992; Nardi et al., 1993). Bencherif et al. (2003) have shown from SAGE II data that the aerosol amounts in the southern subtropical UTLS decreased gradually to return to normal levels by late 1995 and early 1996 .

Once post-Pinatubo data (June 1991-December 1995) were removed, linear trends in temperature at all UTLS pressure levels were estimated. Figure 4a shows the vertical distribution of the linear trend in temperature per decade as derived from Durban morning data. A cooling trend is observed at almost all heights in the UTLS region $(250-20 \mathrm{hPa})$. The maximum cooling rate is $1.09 \pm 0.41 \mathrm{~K}$ per decade, and is observed in the lower stratosphere, at 70-hPa.

For comparison, daily morning data from an additional South-African subtropical site, Upington $\left(28.5^{\circ} \mathrm{S}, 21.3^{\circ} \mathrm{E}\right)$, has been examined for the January 1980-March 1999 period. Upington temperature trends are shown with star symbols on Fig. 4a. Both sites show nearly similar trend values, notably in the stratosphere. In the troposphere, unlike the Durban trends (slightly negative: $-0.10 \mathrm{~K} /$ decade), those estimated for Upington are almost equal to zero $(-0.02 \mathrm{~K} /$ decade). The small tropospheric discrepancy can be related to the site locations and indeed to the associated tropospheric regimes. Indeed, Durban is a coastal site, while Upington is a continental one. Moreover, the highest cooling rate over Upington is obtained in the lower stratosphere $(-1.12 \pm 0.53 \mathrm{~K} /$ decade $)$ at the same pressure level as for Durban $(70 \mathrm{hPa})$.

Figure $4 \mathrm{~b}$ depicts the time evolution of mean monthly temperatures in the lower stratosphere (at 70-hPa) over Durban, with the cooling trend line superimposed. 

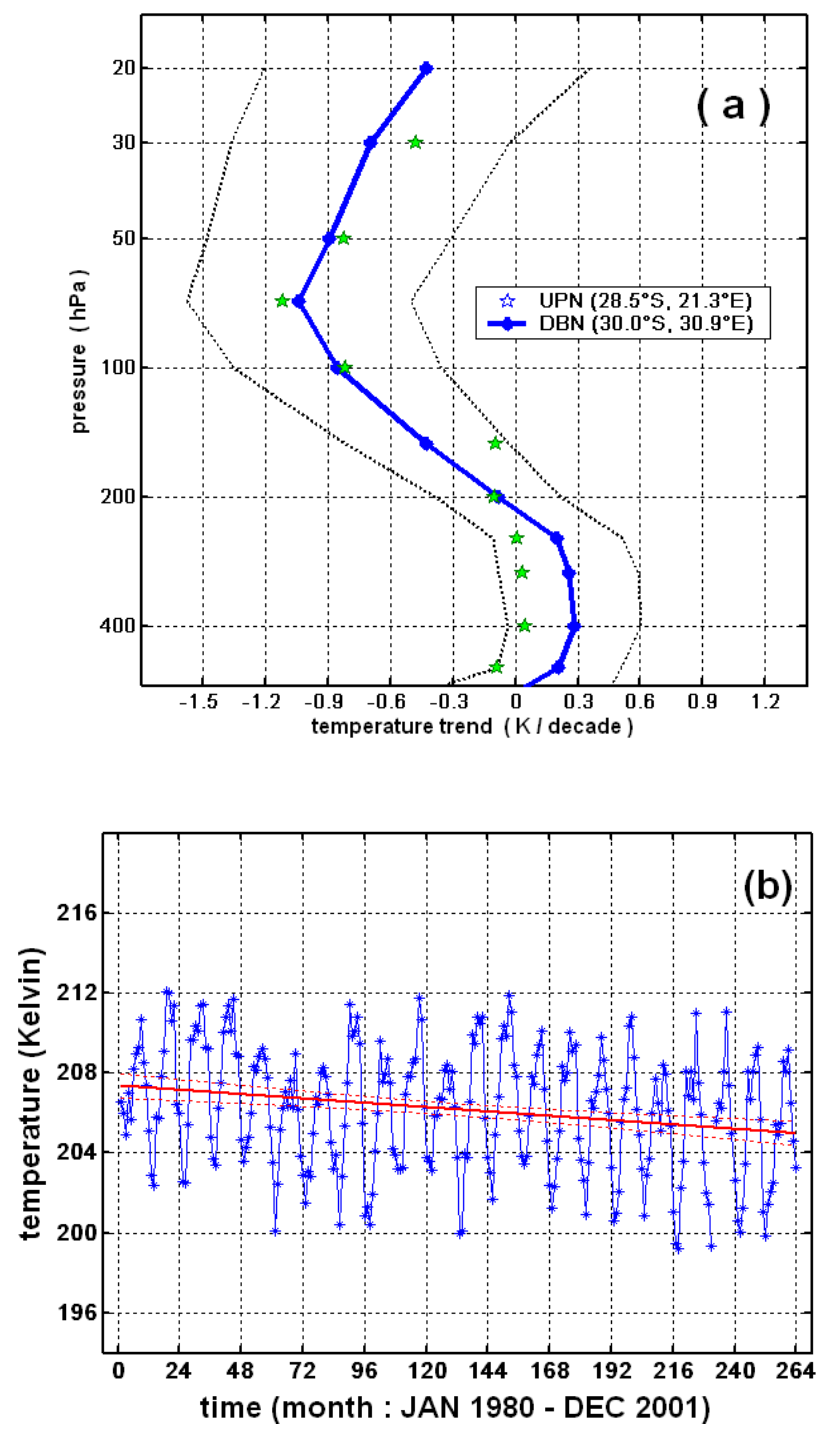

Fig. 4. (a) Linear temperature trend (in Kelvin per decade) height profile framed with the $95 \%$ confidence profiles, derived from Durban: DBN $\left(30.0^{\circ} \mathrm{S}, 30.9^{\circ} \mathrm{E}\right)$ morning data. Upington (UPN: $\left.28.5^{\circ} \mathrm{S}, 21.3^{\circ} \mathrm{E}\right)$ trends retrieved from during January 1980-March 1999 period are shown with star symbols. (b) Time evolution of the monthly averaged temperature values in the lower stratosphere (at $70 \mathrm{hPa}$ ), over Durban. The superimposed red line indicates the obtained linear trend, i.e., $-1.09 \pm 0.41 \mathrm{~K}$ per decade.

As mentioned above, morning and afternoon data have been used separately. In order to examine how do atmospheric tides affect the diurnal cycle of temperature trends at different altitudes, Fig. 5 shows the linear trend profiles as derived from morning and afternoon Durban datasets. The differences between morning and afternoon trends are superimposed (see legend). Both morning and afternoon trends show globally the same shape. However, the afternoon cooling rate is more stressed in the UTLS. The maximum cooling rate from afternoon dataset is obtained in the lower stratosphere $(-1.88 \mathrm{~K} /$ decade, at $50 \mathrm{hPa})$.

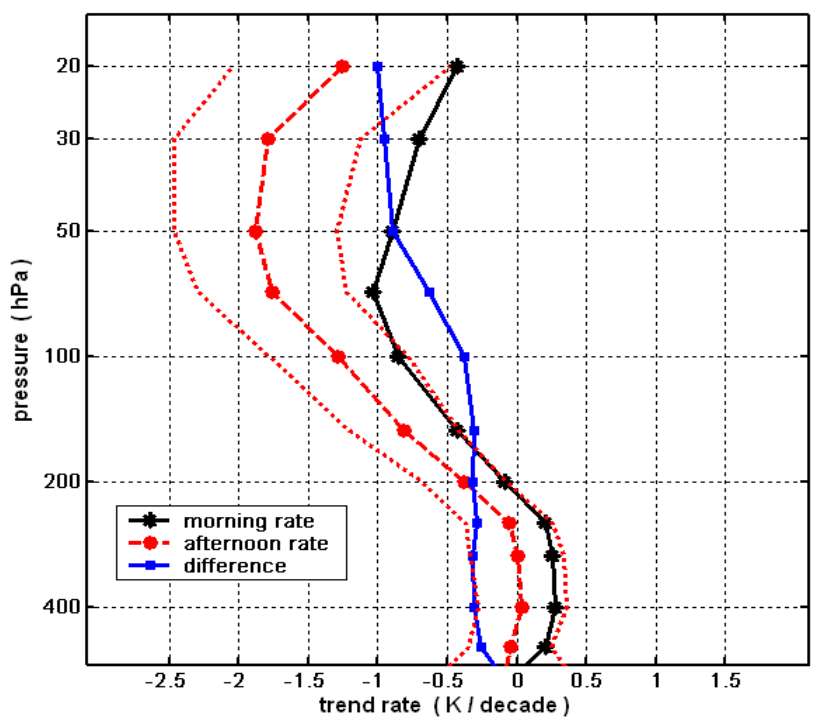

Fig. 5. Morning and afternoon linear trends and differences, as derived from Durban datasets (see legend).

Besides, the trend absolute difference between morning and afternoon datasets is almost constant in the troposphere (including at the tropopause, i.e., $100 \mathrm{hPa}$ ), and is increasing in the stratosphere. This result suggests that the trend difference may be associated to ozone $\left(\mathrm{O}_{3}\right)$ change in the stratosphere. Indeed, the stratospheric $\mathrm{O}_{3}$ is photo-chemically active, and shows a negative trend ( $-6 \%)$, (UNEP/WMO, 2002). Moreover, atmospheric tides are global-scale oscillations that are primarily induced by the diurnal variation of solar radiation absorption, mainly by water vapour $\left(\mathrm{H}_{2} \mathrm{O}\right)$ in the troposphere $(\sim 1 / 3)$ and $\mathrm{O}_{3}$ in the stratosphere $(\sim 2 / 3)$ (Strobel, 1978). Any change in $\mathrm{H}_{2} \mathrm{O}$ and/or $\mathrm{O}_{3}$ concentrations may induce a change on tidal structures, as reported by Morel et al. (2004). In fact, Morel et al. examined, in a 3-D Dynamics-chemistry-transport model, the sensitivity of the tidal amplitudes to decadal changes of the thermal source distributions, notably changes in $\mathrm{O}_{3}$ and $\mathrm{H}_{2} \mathrm{O}$ distributions; and found that the largest changes occur at tropical and subtropical latitudes.

Yet, despite their weak amplitudes in the stratosphere (less than $1 \mathrm{~K}$ ), and because of their mode of generation, tide variations seem to affect the trend of temperature diurnal cycle at different heights and exacerbate, as shown on Fig. 5, the stratospheric cooling.

It comes out from Durban morning dataset that the mean tropospheric $(400-100 \mathrm{hPa})$ and stratospheric $(70-20 \mathrm{hPa})$ temperature trends are $0.10 \pm 0.18$ and $-0.76 \pm 0.32 \mathrm{~K} / \mathrm{dec}$ ade, respectively. The cooling rate in the lower stratosphere is indeed significant and higher than in the upper troposphere. It is noted that for tropospheric heights below the $200-\mathrm{hPa}$ height, temperature trend rates are found to be positive but not significant. 
Table 2. Upper troposphere and lower stratosphere temperature trends (K per decade) from published studies and from the current study.

\begin{tabular}{lllll}
\hline & Angel (1988) & Oort and Liu (1993) & Parker et al. (1997) & Current study \\
& $1959-1988$ & $1964-1988$ & $1979-1996$ & $1980-2001$ \\
\hline Upper Troposphere & $-0.16 \pm 0.11$ & $-0.11 \pm 0.11$ & -0.11 & $-0.10 \pm 0.18$ \\
Lower Stratosphere & $-0.64 \pm 0.29$ & $-0.43 \pm 0.16$ & -0.73 & $-0.76 \pm 0.32$ \\
\hline
\end{tabular}

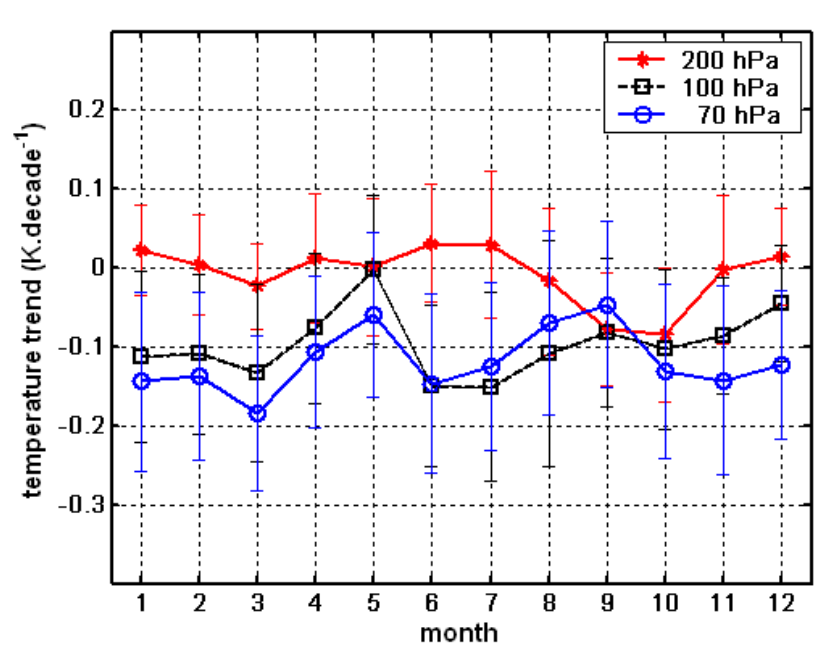

Fig. 6. Monthly seasonal decomposition of temperature trends (in Kelvin per year) at 200-, 100- and 70-hPa pressure levels (see legend).

Using a global rawinsonde network Oort and Liu (1993) considered the latitudinal structure of long-term trends for the 1968-1988 period. They obtained cooling trends in the SH UTLS region that increased with latitude from the tropics to the South Pole. More recently, Parker et al. (1997) have combined the rawinsonde data from the Australian region with the satellite-based Microwave Sounding Unit (MSU) retrievals, to calculate temperature trends over the period 1979-1996. They also found cooling trends in the southern UTLS, notably at subtropical latitudes.

Stratospheric and tropospheric temperature trends as derived by Angell (1988), Oort and Liu (1993) and Parker et al. (1997) are compared with values obtained in this study in Table 2. The cooling rate obtained in the lower stratosphere appears to be the most important. It is in good agreement with the other results, taking into account that the periods of analysed datasets are not identical.

A study on the variance and standard deviation (STD) of the mean temperature over a region is considered important for climatological use. Variability is defined as the STD of all temperature observations relevant to a given month. Monthly average temperature variability (STD) obtained for Durban is reported in Table 1. From March to October STD values are found to be relatively higher in the troposphere, including at the tropopause level $(100 \mathrm{hPa})$, in comparison with stratospheric levels. Yet, at all pressure levels, STD shows a maximum during austral winter, i.e., during July and August. The highest temperature STD value over Durban is obtained at $200 \mathrm{hPa}$ in July; while the highest STD in the lower stratosphere is recorded during the June-July period, at $70 \mathrm{hPa}$. This is most likely related to temperature variations caused by the development of synoptic disturbances in the troposphere in winter. Indeed, such wave disturbances propagate vertically through to the stratospheric layers in the winter hemisphere when the zonal winds are westerly (Charney and Drazin, 1961). Hauchecorne et al. (1987) have also drawn attention to the role of wintertime propagations of planetary and gravity waves as the causes of increases in temperature variability.

In order to understand the seasonal characteristics of temperature trends, knowledge of trends in dynamical activity is needed. Dynamical trends in the UTLS may be induced by changes in concentrations of radiatively active gases or by any tropospheric changes.

In the present study, having separated the initial dataset into monthly time-series, the least-squares model (introduced above) was applied separately to the 12-month time-series in order to derive the seasonality of temperature trends. Figure 6 shows monthly trend estimates as derived at tropospheric and stratospheric levels (200-, 100- and 70-hPa). Taking into account the reduction in size of the datasets, the derived seasonal trends may be used qualitatively, but should not be used as a precise quantitative result.

In the troposphere, monthly trends are almost equal to zero, except for September and October when the cooling rates are similar to stratospheric values (about $-0.8 \mathrm{~K} /$ decade). At the tropopause, seasonal trends show the same variations as obtained in the stratosphere. However, the maximum cooling at the tropopause (obtained by June-July period) does not coincide with the maximum cooling in the stratosphere (obtained by March). With regard to the minimum cooling rate in the stratosphere, it occurs by May and September (by early and late winter, respectively).

As suggested above, the seasonal dependence of temperature trends may be related to trends in wave activity in the southern UTLS. In fact, Using ECMWF-ERA40 reanalyses and temperature profiles obtained with a Rayleigh 
Lidar operating at Durban, Bencherif et al. (2000) showed that temperature variability increases by early winter (May), when the transition of the stratospheric zonal-mean winds to the westerly regime occurs and the planetary Rossby waves propagate upward. Moreover, Bodeker and Scourfield (1995), using TOMS data recorded over the period 19791992 and an EOF analysis on the vertical component of Eliassen-Palm flux, have reported an increasing trend in wave activity during winter in the southern UTLS. This is consistent with our seasonal analysis and shows that in the lower stratosphere, trends in temperature should be examined in conjunction with trends in dynamics.

\section{Conclusion}

Daily radiosonde data over Durban $\left(30.0^{\circ} \mathrm{S}, 30.9^{\circ} \mathrm{E}\right)$, which is situated on the east coast of South Africa, over the period January 1980 to December 2001, i.e. 22 years, were used to derive a mean temperature climatology and to determine trends in temperature in the upper-troposphere and lowerstratosphere (UTLS) region. Previous studies have highlighted the importance of this region because of the many dynamical processes that occur here and their role in the vertical and horizontal transfer of energy, mass and atmospheric constituents.

The mean seasonal temperature climatology revealed differences between the upper troposphere and the lower stratosphere. The seasonal cycle of temperature at the $250-\mathrm{hPa}$ height is anti-correlated with that at $150-\mathrm{hPa}$ and $100-\mathrm{hPa}$. The 100-hPa level (tropopause) exhibits a minimum temperature in late summer (February) and a maximum in winter (June to August), and closely corresponds to the results obtained by Randel et al. (2000) for tropical regions.

A Fourier analysis performed at different heights highlighted two dominant seasonal oscillations: an annual (AO) and a semi-annual oscillation (SAO). The former is dominant (about 4 times stronger) in the UTLS region and maximises at the 100-hPa height, whereas the SAO has its maximum amplitude at 250-hPa, where the $\mathrm{AO}$ is at its minimum.

A trend analysis based on a multivariate least-squares regression technique was undertaken. Seasonal variations (both $\mathrm{AO}$ and SAO), the QBO, the ENSO and the 11-year solar cycles were taken into account. Furthermore, the data were adjusted for the influence of the Pinatubo eruption. Cooling trends were observed at almost all heights in the UTLS region $(250-20 \mathrm{hPa})$, although cooling rates in the lower stratosphere were higher than in the upper troposphere. The maximum cooling rate of $1.09 \pm 0.41 \mathrm{~K}$ per decade was observed at the 70-hPa height. For comparison, temperature trends from daily morning data obtained at Upington $\left(28.5^{\circ} \mathrm{S}, 21.3^{\circ} \mathrm{E}\right)$, show nearly similar trends as for Durban, notably in the stratosphere.

Moreover, when comparing trends derived from Durban morning and afternoon datasets, tide variations seem to af- fect the trend of temperature diurnal cycle at different heights and exacerbate the cooling rate in the lower stratosphere (see Fig. 6). This may be related to the mode of generation of tidal structures. Indeed, atmospheric tides are induced by the diurnal variation of solar radiation absorption, mainly by $\mathrm{H}_{2} \mathrm{O}$ in the troposphere and $\mathrm{O}_{3}$ in the stratosphere.

It comes out from the seasonal trend decomposition that reduction of the cooling rate in the lower stratosphere passes by two maximums: early and late winter (May and September, respectively).

Temperature variability as indicated by the magnitude of the standard deviation was found to be higher in the troposphere than in the stratosphere and also to be greater in winter. The higher temperature variations in winter were attributed to the greater frequency of tropospheric synoptic disturbances in winter and to the vertical propagation of such wave disturbances through the stratosphere under westerly zonal winds.

Acknowledgements. We thank the two anonymous referees for constructive suggestions and comments on this paper. We are grateful to the South African Weather Service (SAWS) for providing upper-air data. We thank F. Sokolic from the School of Environmental Sciences, University of KwaZulu-Natal. This work was undertaken under the French-South African co-operative programme and supported by the French Centre National de la Recherche Scientifique (CNRS), the South African National Research Foundation (NRF) and the Regional Council, Conseil Régional de La Réunion.

Edited by: M. G. Lawrence

\section{References}

Angell, J. K.: Variations and trends in tropospheric and stratospheric global temperatures, 1958-87, J. Climate, 1(12), 12961313, 1988.

Baray, J. L., Ancellet, G., Taupin, F. G., Bessafi, M., Baldy, S., and Keckhut, P.: Subtropical tropopause break as a possible stratospheric source of ozone in the tropical troposphere, J. Atmos. Sol.-Terr. Phys., 60, 27-36, 1998.

Baray, J. L., Daniel, V., Ancellet, G., and Legras, B.: Planetaryscale tropopause folds in the southern subtropics, Geophys. Res. Lett., 27, 353-356, 2000.

Bencherif, H., Morel, B., Moorgawa, A., Michaelis, M., Leveau, J., Porteneuve, J., Hauchecorne, A., and Faduilhe, D.: Observation and first validation of stratospheric temperature profiles obtained by a Rayleigh-Mie LIDAR over Durban, South Africa, South African J. Sci., 96, 487-492, 2000.

Bencherif, H., Portafaix, T., Baray, J. L., Morel, B., Baldy, S., Leveau, J., Moorgawa, A., Michaelis, M. M., Hauchecorne, A., Keckhut, P., and Diab, R.: LIDAR observations of lower stratospheric aerosols over South Africa linked to large scale transport across the southern subtropical barrier, J. Atmos. Sol.-Terr. Phys., 65, 707-715, 2003.

Bodeker G. E. and Scourfield M. W. J.: Planetary waves in total ozone and their relation to Antarctic ozone depletion, Geophys. Res. Lett., 22(21), 2949-2952, 1995. 
Bodeker, G. E., Boyd, I. S., and Matthews, W. A.: Trends and variability in vertical ozone and temperature profiles measured by ozonesondes at Lauder, New-Zealand: 1986-1996, J. Geophys. Res., 103(D22), 28 661, 1998.

Charney, J. G. and Drazin, P. G.: Propagation of planetary-scale disturbances from the lower into the upper atmosphere, J. Geophys. Res., 66, 83-109, 1961.

Gaffen, D. J.: Temporal inhomogeneities in radiosonde temperature records, J. Geophys. Res., 99(D2), 3667-3676, 1994.

Grant, W. B., Browell, E. V., Fishman, J., Brakett, V. G., Veiga, R. E., Nganga, D., Minga, A., Cros, B., Butler, C. F., Fenn, M. A., Long, C. S., and Sowe, L. L.: Aerosol associated changes in tropical stratospheric ozone following the eruption of Mount Pinatubo, J. Geophys. Res., 99(D4), 8197-8211, 1994.

Guirlet M., Keckhut, P., Godin, S., and Megie, G.: Description of the long-term ozone data series obtained from different instrumental techniques at a single location: the Observatoire de Haute-Provence $\left(43.9^{\circ} \mathrm{N}, 5.7^{\circ} \mathrm{E}\right)$, Ann. Geophys., 18, 13251339, 2000, http://www.ann-geophys.net/18/1325/2000/.

Harris, N. R. P., Ancellet, G., Bishop, L., Hofmann, D. J., Kerr, J. B., McPeters, R. D., Prendez, M., Randel, W. J., Staehelin, J., Subbaraya, B. H., Volz-Thomas, A., Zawodny, J., and Zerefos, C. S.: Trends in stratospheric and free tropospheric ozone, J. Geophys Res., 102(D1), 1571-1590, 1997.

Hauchecorne, A. and Wilson, R.: Mesospheric temperature inversion and gravity wave breaking, Geophys. Res. Lett., 14, 933936, 1987.

Hauchecorne, A., Chanin, M. L., and Keckhut, P.: Climatology and trends of the middle atmospheric temperature $(33-87 \mathrm{~km})$ as seen by Rayleigh lidar over the south of France, J. Geophys. Res., 96, 15 267-15309, 1991.

Holton, J. R., Haynes, P. H., McIntyre, M. E., Douglas, A. R., Rood, R. B., and Pfister, L.: Stratosphere-Troposphere Exchange, Rev. Giophys., 33, 403-439, 1995.

Keckhut, P., Hauchecorne, A., and Chanin, M. L.: Mid-latitude long-term variability of the middle atmosphere : trends and cyclic and episodic changes, J. Geophys. Res., 100, 9263-9272, 1995.

Keckhut, P., Schmidlin, F. J., Hauchecorne, A., and Chanin, M.-L.: Trend estimates from rocketsondes at low latitude station (8 S$34 \mathrm{~N}$ ), taking into account instrumental changes and natural variability, J. Atmos. Sol. Terr. Phys., 61, 447-459, 1999.

Kokin, G. and Lysenko, E.: On temperature trends of the atmosphere from rocket and radiosonde data, J. Atmos. Terr. Phys., 56, 1035-1044, 1994.

Labitzke, K. and McCormick M. P.: Stratospheric temperature increases due to Pinatubo aerosols, Geophys. Res. Lett., 19(2), 207-210, 1992.

Logan, J. A.: Trends in the vertical distribution of ozone: An analysis of ozonesonde data, J. Geophys. Res., 99(D12), $25553-$ 25 586, 1994.
McCormick, M. P. and Veiga, R. E.: SAGE II measurements of early Pinatubo aerosols, Geophys. Res. Lett., 19, 155-158, 1992.

Mohanakumar, K.: Temperature variability over the tropical middle atmosphere, Ann. Geophys., 12, 448-456, 1994, http://www.ann-geophys.net/12/448/1994/.

Morel, B., Keckhut, P., Bencherif, H., Hauchecorne, A., Mégie, G., and Baldy, S.: Investigation of the tidal variability in a 3-D dynamics- chemistry- transport model of the middle atmosphere, J. Atmos. Sol.-Terr. Phys., 66, 251-265, 2004.

Nardi, B, Chanin, M.-L., Hauchecorne, A., Avdyushin, S. I., Tulinov, G. F., Ivanov, M. S., Kuzmenko, B. N., and Mezhuev, I. R.: Morphology and dynamics of the Pinatubo aerosol layer in the Northern Hemisphere as detected from a ship-borne lidar, Geophys. Res. Lett., 20(18), 1967-1970, 1993.

O'Connor, F. M., Vaughan, G., and De Backer, H.: Observation of subtropical air in the European mid-latitude lower stratosphere, Quart. J. Roy. Meteorol. Soc., 125, 2965-2986, 1999.

Oort, A. H. and Liu, H.: Upper-air temperature trends over the globe, 1958-1989, J. Clim., 6, 292-307, 1993.

Parker, D. E., Gordon, M., Cullum, D. P. N., Sexton, D. M. H., Folland, C. K., and Rayner, N.: A new global gridded radiosonde temperature database and recalculated temperature trends, Geophys. Res. Lett., 24, 1499-1502, 1997.

Portafaix, T., Morel, B., Bencherif, H., Godin-Beekmann, S., Baldy, S., and Hauchecorne, A.: Fine scale study of a thick stratospheric ozone lamina at the edge of the southern subtropical barrier, J. Geophys. Res., 108(D6), 4196, doi:10.1029/2002002741, 2003.

Ramaswamy, V., Chanin, M.-L., Angell, J., Barnett, J., Gaffen, D., Gelman, M., Keckhut, P., Koshelkov, Y., Labitzke, K., Lin, J.-J. R., O’Neill, A., Nash, J., Randel, W., Rood, R., Shine, K., Shiotani, M., and Swinbank, R.: Stratospheric temperature trends: observations and model simulations, Rev. Geophys., 39(1), 71122, 2001.

Randel, W. J., Wu, F., and Gaffen, D. J.: Interannual variability of the tropical tropopause derived from radiosonde data and NCEP reanalyses, J. Geophys. Res., 105(D12), 15 509-15 524, 2000.

Strobel, D. F.: Parameterization of the atmospheric heating rate from 15 to $120 \mathrm{~km}$ due to $\mathrm{O}_{2}$ and $\mathrm{O}_{3}$ absorption of solar radiation, J. Geophys. Res., 83, 6225-6230, 1978.

Tiao, G. C., Xu Daming, Pedrick, J. H., Zhu Xiaodong, and Reinsel, G. C.: Effect of autocorrelation and temporal schemes on estimates of trend and spatial correlation, J. Geophys. Res., 95, 20 507-20 517, 1990.

Vaughan, G. and Timmis, C.: Transport of near-tropopause air into the lower midlatitude stratosphere, Quart. J. Roy. Meteorol. Soc., 124(549), 1559-1578, 1998.

WMO: Scientific assessment of ozone depletion: 1994, Global Ozone Res. and Monit. Proj., Rep. 37, 1995.

WMO: Scientific assessment of ozone depletion: 1998, Global Ozone Res. and Monit. Proj., Rep. 44, 1999.

WMO: Scientific assessment of ozone depletion: 2002, Global Ozone Res. and Monit. Proj., Rep. 47, 2002. 